Tropical Journal of Pharmaceutical Research, August 2009; 8 (4): 311-316

(C) Pharmacotherapy Group, Faculty of Pharmacy, University of Benin,

Benin City, 300001 Nigeria.

All rights reserved.

Research Article

Available online at http://www.tjpr.org

\title{
In-vivo Kinetics of Silymarin (Milk Thistle) on Healthy Male Volunteers
}

\section{Muhammad Usman*, Mahmood Ahmad, Asad Ullah Madni, Naveed Akhtar, Waheed Asghar, Muhammad Akhtar, M Atif and M Qamar-uz-zaman}

Department of Pharmacy, the Islamia University of Bahawalpur, Punjab, Pakistan.

\begin{abstract}
Purpose: The study was aimed at evaluating the in vivo kinetics of silymarin tablets, a product with antihepatotoxic and free radical scavenging activities.

Methods: Silimarin ${ }^{\circledR}$ (Amson Vaccines \& Pharma Pvt Ltd) was used as the test product while another silymarin tablet brand, Silliver ${ }^{\circledR}$ (Abbott Laboratories Pak Ltd) was the reference product. The tablets were administered to healthy male volunteers orally at a dose of $200 \mathrm{mg}$ following an overnight fast according to a randomized cross-over design. Scheduled blood samples were collected, centrifuged and the plasma assayed using a sensitive and validated reversed phase high performance liquid chromatographic (RP-HPLC) method. Various pharmacokinetic parameters were calculated based on the non-compartmental model.

Results: Non-significant difference $(p<0.05)$ was observed in the area under the curve $(A \cup C)$ of the two brands with values of $10.8 \pm 0.4 \mu \mathrm{g} \mathrm{h} / \mathrm{ml}$ and $11.2 \pm 0.7 \mu \mathrm{g} \mathrm{h} / \mathrm{ml}$, respectively. There was, however, a significant difference $(p<0.05)$ in the $C_{\max }$ of the two brands. Other pharmacokinetic parameters evaluated did not show any statistical difference $(p<0.05)$ between the two products except for mean residence time

Conclusion: The test product can be used as an alternative to the brand, Silliver ${ }^{\circledR}$-Abbot (reference), only in conditions where maximum plasma concentration $\left(C_{\max }\right)$ is not an important consideration.
\end{abstract}

Keywords: In vivo kinetics, Silymarin, Milk thistle, RP-HPLC, Pharmacokinetics. 


\section{INTRODUCTION}

Silymarin is an active extract of the seeds of Silybum marianum (milk thistle) ${ }^{1}$. A standardized extract of the seed contains approximately $\quad 70-80 \%$ of silymarin flavonolignans and $20-30 \%$ chemically undefined fraction, comprising mostly polymeric and oxidized polyphenolic compounds ${ }^{2}$.<smiles>COc1cc(P2Oc3ccc([C@@H]4Oc5cc(O)cc(O)c5C(=O)C(O)[C@H]4O)cc3OB2CO)ccc1O</smiles>

$\mathrm{A}, \mathrm{B}=$ Diastereomers

$A=\beta-H 12 ; \alpha-H 13$

$B=\alpha-H 12 ; \beta-H 13$<smiles>COc1ccc(P2Oc3ccc([C@@H]4Oc5cc(O)cc(O)c5C(=O)[C@H](O)[C@H]4OCO)cc3O2)cc1O</smiles>

$\mathrm{A}, \mathrm{B}=$ Diastereomers

$A=\beta-H 12 ; \alpha-H 13$

$B=\alpha-H 12 ; \beta-H 13$<smiles>COc1cc(C2Oc3ccc([C@@H]4Oc5cc(O)cc(O)c5C(=O)[C@H]4O)cc3[C@H]2CO)ccc1O</smiles>

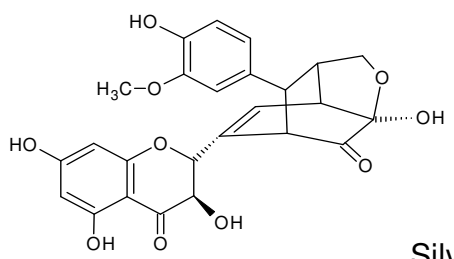

Silydianin

Figure 1: Structure of silymarin components.

The main component of silymarin (Figure 1) is silybin or silibinin which is a mixture of diastereomers, namely, silybin A and silybin B. Isosilybin, dehydrosilybin, silychristin, silydianin are present in considerable amounts and a few flavonoids, such as taxifolin, are also present but in small amounts $^{2}$. It is reported in literature that silymarin does not possess high bioavailability $^{3-8}$. Silymarin absorption rate levels are between 20 and $50 \%{ }^{6}$. In fact, this poor bioavailability could be attributed to degradation by gastric fluid $^{6}$, poor enteral absorption $^{5,8}$ or its poor water solubility ${ }^{3,4,6,7}$. Silymarin (an extract from Silybum marianum) contains silybin as a main component and, therefore, pharmacokinetic and bioavailability studies are always based on the determination of silybin in plasma $^{9-11}$. Complex composition and the ever-increasing list of their putative active constituents in an herbal extract make bioavailability and pharmacokinetic studies problematic and task becomes even more difficult when the active constituents and synergistic interactions are not fully known ${ }^{12}$. Silymarin is one of the few herbal drugs whose active constituents have been sufficiently studied and on which bioavailability studies are possible ${ }^{13}$.

Therefore, this work was designed and conducted to provide pharmacokinetic data on silymarin tablets that would facilitate the rational usage of this valuable medicinal agent, which is widely used in a variety of situations, especially in liver diseases.

\section{EXPERIMENTAL}

\section{Subjects and Methods}

Healthy male volunteers ranging in age from $22-40$ years $(23.1 \pm 0.4$ years), in weight from $55-70 \mathrm{~kg}(62.5 \pm 1.3 \mathrm{~kg})$, and in height from $165-180 \mathrm{~cm}(176.0 \pm 1.8 \mathrm{~cm})$ were enrolled according to the inclusion/exclusion criteria of Food and Drug Administration (FDA) ${ }^{14}$. Pharmacy Ethical Committee of the Faculty of Pharmacy and Alternative Medicine, the Islamia University of Bahawalpur, approved the study protocols for the human studies. Written informed consent was obtained from 
each volunteer who received an oral dose $(200 \mathrm{mg})$ of silymarin of both products according to a randomized cross-over design. A washout period of one week was allowed between the two treatments. The subjects were housed at the study centre throughout period of blood sampling. Approximately $3 \mathrm{ml}$ aliquot of blood sample was collected predose (to serve as a control), and over a period of $12 \mathrm{~h}$ after sylimarin administration. The blood was centrifuged immediately and plasma was stored at $-70{ }^{0} \mathrm{C}$ until HPLC analysis.

\section{HPLC analysis}

\section{Preparation of the mobile phase}

The mobile phase consisted of methanol and potassium dihydrogen phosphate buffer (20 $\mathrm{mM}$ ) in a ratio of $50: 50 \mathrm{v} / \mathrm{v}$ with the $\mathrm{pH}$ of the buffer adjusted to 2.8 with phosphoric acid. It was filtered through a $0.45 \mu \mathrm{m}$ membrane filter before use. The flow rate was $1 \mathrm{ml} / \mathrm{min}$ at $30{ }^{\circ} \mathrm{C}$. Detection was performed at 288 $\mathrm{nm}^{15}$.

\section{Preparation of stock solutions}

A stock solution of silymarin was prepared fresh by dissolving $50 \mathrm{mg}$ drug in $50 \mathrm{ml}$ of methanol to give a final concentration of 1 $\mathrm{mg} / \mathrm{ml}$. Working solutions of silymarin were prepared in the mobile phase by appropriate dilution $(2.5,15,30,62.5,125,250$ and 500 $\mu \mathrm{g} / \mathrm{ml})$. All the solutions were stored at -20 ${ }^{0} \mathrm{C}$, protected from light.

\section{Preparation of standard curve}

A standard curve was constructed to encompass anticipated range of plasma silymarin concentration found in healthy volunteers. The curve was prepared by spiking different samples of $1 \mathrm{ml}$ plasma each with $20 \mu \mathrm{l}$ of one of the working solutions to produce calibration curve points equivalent to $0.05,0.3,0.6,1.25,2.5,5.0$ and $10 \mu \mathrm{g} / \mathrm{ml}$ of silymarin. Aliquots of $100 \mu \mathrm{l}$ were injected and spectra were taken in each case and the peak areas noted. The intra-day (within-run) and inter-day (between-run) accuracy and precision of the method were determined on three separate days.

\section{Extraction procedure}

An aliquot $(100 \mu \mathrm{l})$ of acetate buffer $(\mathrm{pH} 5.6)$ and a $30 \mu \mathrm{l}$ aliquot of $\beta$-glucuronidase Type HP-2 (Helix pomatia-Merck, Germany, 1,27300 units $/ \mathrm{ml}$ ) were added to a $100 \mu \mathrm{l}$ aliquot of plasma sample and the mixtures were incubated at $37 \mathrm{C}^{\circ}$ for $2 \mathrm{~h}$ with periodical shaking. Then $200 \mu$ l of borate buffer $(\mathrm{pH} 8.5)$ and $2.0 \mathrm{ml}$ of diethyl ether were added to the mixture. The mixture was vortexed for $1 \mathrm{~min}$ and centrifuged at 3000 rpm for $2 \mathrm{~min}$. The organic phase was transferred into a clean sample test tube and evaporated under a gentle stream of nitrogen. The residue was reconstituted in a $130 \mu \mathrm{l}$ aliquot of the mobile phase, vortexed for 30 seconds and centrifuged for $1 \mathrm{~min}$ at 2500 $\mathrm{rpm}$, and then $100 \mu \mathrm{l}$ of the solution was injected directly into the chromatographic system $^{15}$.

\section{Pharmacokinetic analysis}

Pharmacokinetic parameters were calculated using the pharmacokinetic software, Kinetica version 4.4 and MS Excel 2007. The rate and extent of absorption was measured by $\mathrm{C}_{\max }$, $\mathrm{T}_{\max }$ and $\mathrm{AUC}_{0-\infty}$ for both the reference and test products. Maximum concentration of silymarin in plasma $\left(\mathrm{C}_{\max }\right)$, time to reach peak plasma concentrations $\left(T_{\max }\right)$ and area under the curve $\left(\mathrm{AUC}_{0-\infty}\right)$ were calculated by the trapezoidal rule. All other parameters plasma half life $\left(t_{1 / 2}\right)$, elimination rate constant $\left(\mathrm{K}_{\mathrm{e}}\right)$, volume of distribution $\left(\mathrm{V}_{\mathrm{d}}\right)$, total body clearance $\left(\mathrm{Cl}_{\mathrm{T}}\right)$ and mean residence time (MRT) - were determined with the aid of the software.

\section{Statistical analysis of data}

Paired t-test was applied for the determination of statistical difference between the values of the bioavailability and 
pharmacokinetic parameters of the two brands of silymarin using Med. Calculator and MS-Excel software at the $95 \%$ confidence level.

\section{RESULTS}

The results of (mean \pm SEM) plasma concentration versus time profiles for all the volunteers that received the treatments are plotted in Figure 2. Table 1 represents the values of bioavailability and other pharmacokinetic parameters. The values of $\mathrm{AUC}_{0-\infty}$ for the two products $(10.8 \pm 0.4$ and $11.2 \pm 0.7 \mu \mathrm{g} \mathrm{h} / \mathrm{ml}$ for the test and reference, respectively) were not significantly different $(\mathrm{P}<0.05)$. The maximum plasma concentration $\left(\mathrm{C}_{\max }\right)$ of the reference and test products were $2.9 \pm 0.3$ and $1.9 \pm 0.1 \mu \mathrm{g} / \mathrm{ml}$, respectively, and the difference was significant $(p<0.05)$. However, the $T_{\max }$ of the reference and test products, which were $1.9 \pm$ 0.1 and $1.8 \pm 0.1 \mathrm{~h}$, respectively, are not significantly different $(P>0.05)$.

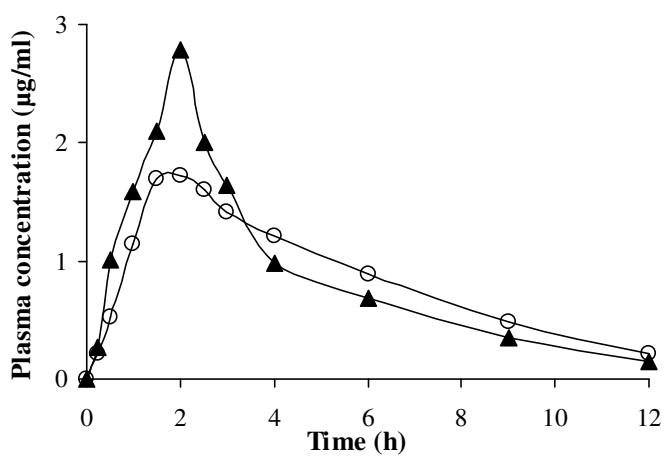

Figure 2: Mean plasma concentration vs time profile of reference product, Silliver ${ }^{\circledR}(\boldsymbol{\Delta})$ and test product, Silimarin ${ }^{\circledR}(\mathrm{O})$.

Other pharmacokinetic parameters evaluated did not show any statistical difference $(P<$ 0.05 ) between the two products except mean residence time which was significantly different. They are (for reference and test products, respectively): elimination rate constant $\left(\mathrm{K}_{\mathrm{e}}\right)-0.3 \pm 0.01$ and $0.2 \pm 0.02 \mathrm{~h}^{-1}$ (in a previous study, $\mathrm{K}_{\mathrm{e}}$ was reported as $0.3 \pm$ $0.08 \mathrm{~h}^{-1}{ }^{16}$ ); mean residence time (MRT) - 4.6 \pm 0.2 and $6.1 \pm 0.4 \mathrm{~h}$; plasma half life $\left(\mathrm{t}_{1 / 2}\right)$ $2.8 \pm 0.1$ and $3.536 \pm 0.403 \mathrm{~h}$; volume of distribution $\left(\mathrm{V}_{\mathrm{d}}\right)-1.2 \pm 0.1$ and $1.5 \pm 0.2$ $\mathrm{L} / \mathrm{Kg}$; total body clearance $\left(\mathrm{Cl}_{\mathrm{T}}\right)-303.5 \pm 44.1$ and $297.4 \pm 62.6 \mathrm{ml} \mathrm{h}^{-1} \mathrm{Kg}^{-1}$

Table 1: Comparative bioavailability and pharmacokinetic parameters of Silliver ${ }^{\circledR}$-Abbott and Silimarin ${ }^{\circledR}$-Amson administered in an oral dose of $200 \mathrm{mg}$ to normal male subjects (mean \pm SEM).

\begin{tabular}{lll}
\hline${ }^{*}$ Parameter & $\begin{array}{l}\text { Silliver }^{\circledR} \\
\text { Abbott }\end{array}$ & $\begin{array}{l}\text { Silimarin }^{\circledR}- \\
\text { Amson }\end{array}$ \\
$\mathrm{C}_{\max }(\mu \mathrm{g} / \mathrm{ml})$ & $2.9 \pm 0.3$ & $1.9 \pm 0.1^{\mathrm{s}}$ \\
$\mathrm{T}_{\max }(\mathrm{h})$ & $1.9 \pm 0.1$ & $1.8 \pm 0.1^{\mathrm{ns}}$ \\
$\mathrm{AUC}(\mu \mathrm{g} \mathrm{h} / \mathrm{ml})$ & $10.8 \pm 0.4$ & $11.2 \pm 0.7^{\mathrm{ns}}$ \\
$\mathrm{MRT}(\mathrm{h})$ & $4.6 \pm 0.2$ & $6.1 \pm 0.4^{\mathrm{s}}$ \\
$\mathrm{t}_{1 / 2}(\mathrm{~h})$ & $2.8 \pm 0.1$ & $3.5 \pm 0.4^{\mathrm{ns}}$ \\
$\mathrm{K}_{\mathrm{e}}\left(\mathrm{h}^{-1}\right)$ & $0.3 \pm 0.01$ & $0.2 \pm 0.02^{\mathrm{ns}}$ \\
$\mathrm{V}_{\mathrm{d}}(\mathrm{L} / \mathrm{Kg})$ & $1.2 \pm 0.1$ & $1.5 \pm 0.2^{\mathrm{ns}}$ \\
$\mathrm{Cl}(\mathrm{ml} / \mathrm{h} / \mathrm{Kg})$ & $303.5 \pm 12.7$ & $297.4 \pm 18.1^{\mathrm{ns}}$ \\
\hline
\end{tabular}

* = pharmacokinetic parameter; $s=$ Signifiant difference $(\mathrm{P}<0.05) ; \mathrm{ns}=$ non signifiant difference $(P>0.05)$

\section{DISCUSSION}

The task of in vivo evaluation of herbal medicines is difficult due to complex composition, ever-increasing list of their putative active constituents and specific analytical method ${ }^{12,13}$. Woo et $\mathrm{al}^{17}$ reported the value of $\mathrm{AUC}_{0-\infty}$ as $22.75 \pm 3.19 \mu \mathrm{g} \mathrm{h} / \mathrm{ml}$ after the administration of silymarin capsule to rats at a dose of $140 \mathrm{mg} / \mathrm{Kg}$. The difference between reported ${ }^{17}$ and present AUC values is due to differences in dose, dosage form, and experimental subjects.

Therefore, it is evident that $A U C_{0-\infty}$ values in the present study a similar trend as in the previous studies. The variation in the values of $\mathrm{C}_{\max }$ of the two brands may be due to differences in the nature and source of the raw materials for the silymarin. It has been well documented that the proportion of active constituents in various silymarins depends largely on the source of Silybum marianum seeds. Moreover, various other factors environmental, cultivation, drying and 
processing procedures - can also influence the concentration of active ingredients. Silymarin is also extracted from the fruits of Silybum marianum instead of the seeds ${ }^{17}$. Silymarin extracted from the fruits of Silybum marianum may contain varied concentration of active principles which can lead to variation in $\mathrm{C}_{\max }$. Another probable reason for the difference in $\mathrm{C}_{\max }$ values may be differences in the extraction procedures for the sylimarins used in the manufacture of the two products. Differences in formulation and processing variables could also have influenced the release of the drugs from the drug products, resulting in dissimilar $C_{\max }$ values. The value of the bioavailability coefficient (F), calculated as 0.96 at $90 \%$ confidence interval, and the area under the curve (AUC) ratio should generally be within the acceptance range of $80-125 \%$.

\section{CONCLUSION}

On the basis of the $F$ (bioavailability coefficient) values and the AUC which fell in the range $80-125 \%$, it can be said that Silimarin ${ }^{\circledR}$-Amson can be used as a substitute for the better known brand, Silliver ${ }^{\circledR}$-Abbott in healthy human subjects except in situations where the maximum plasma concentrations of the latter must be attained, e.g., in acute conditions such as acute pain. However, the test product should be suitable for use in chronic conditions such as hepatitis.

\section{ACKNOWLEDGEMENT}

The authors are thankful to Amson Vaccines \& Pharma (Pvt.) Ltd, Islamabad, Pakistan for their support for this study

\section{REFERENCES}

1. Morazzoni $P$, Bombardelli E. Silybum marianum (Carduus marianus). Fitoterapia, 1995; 64: 342.

2. Kren V, Walterova D. Silybin and Silymarin - New effects and Applications. Biomed Papers, 2005; 149: 29-41.
3. Madaus $R$, Halbach $G$, Trost $W$. Salt of the silymarin group with aminopolyhydroxy alcohols. U.S, Patent 30 November, 1976; 3: 994-925.

4. Gabetta B, Bombardelli E, Pifferi G. Complexes of flavanolignans with phospholipids, preparation thereof and associated pharmaceutical compositions. U.S. Patent 16 August, 1988; 4 764-508.

5. Comoglio A, Tomasi S, Malandrino G, Poli $E$ Albano. Scavenging effect of silipide, a new silybin-phospholipid complex on ethanolderived free radicals. Biochem. Pharmcol, 1995; 50:1313-1316.

6. Blumenthal M, Goldberg A, Brinckmann J. Herbal Medicine. Expanded Commission $E$ Monographs, Newton, MA, Integrative Medicine Communications, 2000; 257-263.

7. Wachter W, Zaeske H. Process for the manufacture of flavonolignan preparation with improved release and absorbability, compositions obtainable thereby and their use for the preparation of pharmaceuticals. U.S. Patent 1 February, 2000; 6 020-384.

8. Giacomelli $S$, Gallo $D$, Apollonio $P$, Ferlini $C$, Distefano M, Morazzoni P, Riva A, Bombardelli E, Mancuso S, Scambia G. Silybin and its bioavailable complex (IdB 1016) potentiate in vitro and in vivo the activity of cisplatin. Life Sci, 2002; 70:1447-1459.

9. Wu W, Wang Y, Que L. Enhanced bioavailability of silymarin by self-microemulsifying drug delivery system. Eur J Pharm Biopharm, 2006; 63: 288-294.

10. Mascher $H$, Kikuta $C$, Weyhenmeyer $R$. Diasteriomeric separation of free and conjugated silibinin in plasma by reversed phase HPLC after specific extraction. J Liquid Chromatogr, 1993; 16:2777-2789.

11. Morazzoni P, Magistretti MJ, Giachetti C, Zanolo G. Comparative bioavailability of silipide, a new flavanolignan complex in rats. Eur Drug Metab Pharmacokinet, 1992; 17:39-4.

12. Ahmad I, Aqil F, Ahmad F, Owais M. Modern Phytomedicine, Turning Medicinal Plants into Drugs, Herbal Medicines:Prospects and Constraints. WILEY-VCH, 2006; pp 59-77.

13. Ernst E, Herbal Medicine. A Concise Overview for Professionals. In: D. Loew, A. Schroedter, Quality and Standardization of Herbal Medicinal Products. Elsevier Health Sciences, 2000; pp 59-68.

14. US Food and Drug Administration. Bioavailability and bioequivalence requirements. Fed Regist, 1992; 57: 17997-18001 [cited 2007 Feb 15]. Available from: http//www.fda.gov/cder/ogd/.

15. Kim YC, Kim EJ, Lee ED, Kim JH, Jang SW, Kim YG, Kwon JW, Kim WB, Lee MG. Comparative bioavailability of Silibinin in healthy male volunteers. Int J Clin Pharmacol Ther, 2003; 41: 593-596.

16. Li W, Gao J, Zhao HZ, Liu CX. Development of a HPLC-UV assay for silybin- 
Usman et al

phosphatidylcholine complex (silybinin capsules) and its pharmacokinetic study in healthy male Chinese volunteers. Eur J Drug Metab Pharmacokinet, 2006; 31:265-70.
17. Woo JS, Kim TS, Park JH, Chi SC. Formulation and Biopharmaceutical Evaluation of Silymarin using SMEDDS. Arch Pharm Res, 2007; 30:82-89. 